\title{
Synthesis and Characterization of Non-linear 6, 8 and 9, 12-Dichloroazaphenothiazine Derivatives
}

\author{
Ayuk Eugene Lakem ${ }^{1, ~ *, ~ N w e k e ~ C l e t u s ~ M . ~}{ }^{1}$, Agu Ifeoma S. ${ }^{2}$ \\ ${ }^{1}$ Chemical Science Department, Faculty of Natural and Applied Sciences, Godfrey Okoye University, Ugwuomu-Nike, Enugu, Nigeria \\ ${ }^{2}$ Department of Chemical Engineering, Institute of Management and Technology, Enugu, Nigeria
}

\section{Email address:}

eugeneayuk@yahoo.com (A. E. Lakem)

\section{To cite this article:}

Ayuk Eugene Lakem, Nweke Cletus M., Agu Ifeoma S. Synthesis and Characterization of Non-linear 6, 8 and 9,

12-Dichloroazaphenothiazine Derivatives. Science Journal of Chemistry. Vol. 4, No. 1, 2016, pp. 9-13. doi: 10.11648/j.sjc.20160401.12

\begin{abstract}
The synthesis of non-linear diaza and tetraaza dichlorophenothiazine derivatives is reported in this article. This was achieved through the thiocyanation of 2,6-diamino-4-chloropyrimidine using potassium thiocyanate, bromine and glacial acetic acid at $-5^{\circ} \mathrm{C}$ to give 2,6-diamino-3-thiocynatopyrimidine, which was hydrolyzed using $20 \%$ sodium hydroxide to furnish 2, 6-diamino-4-chloropyrimidin-3-thiol. Base catalyzed condensation reaction of 2, 6-diamino-4-chloropyrimidin-3thiol and 2, 3-dichloro-1, 4-naphthoquinone gave the first derivative, 10-amino-6, 8-dichloro-9, 11-diazabenzo [a] phenthiazin5-one, a reddish crystalline product. Similarly, another condensation reaction of 2, 6-diamino-4-chloropyrimidin-3-thiol with the first derivative, 10-amino-6, 8-dichloro-9, 11-diazabenzo[a]phenthiazin-5-one using the same reaction conditions, furnished the second derivative known as 7, 14-diamino-9,12-dichloro-6, 8, 13, 15-tetraazabenzo [a] [1,4] benzothiazino-[3,2c] phenothiazine, a deep reddish crystalline compound. The synthesized compounds were characterized on the basis of UVVisible, IR, ${ }^{1} \mathrm{HNMR}$ and ${ }^{13} \mathrm{CNMR}$ spectra data.
\end{abstract}

Keywords: Synthesis, Hydrolysis, Condensation, Crystalline, Derivatives

\section{Introduction}

The chemistry of phenothiazine 1 and its derivatives has remained unabated. These groups of heterocyclic compounds play important roles in medicinal chemistry [1]. For the past two centuries, attention has been focused on the synthesis of phenothiazine and its derivatives as well as their screening for biological activities [2]. Phenothiazine derivatives are very important because they exhibit a wide range of applications. Their usage as drugs, antioxidants in petroleum, thermal stabilizers, pesticides, light sensitive (photographic) materials, dyes and high temperature lubricants make their chemistry very interesting [3]-[9].

Any variation in the substitution pattern of the phenothiazine nucleus often causes a marked difference in activity, for this reason many phenothiazine derivatives with different substituents have being synthesized, characterized and screened for biological activities in order to produce better drugs [10], [11]. For instance the non-linear azaphenothiazine derivatives of the types 2 and 3 with monohalide atoms have been synthesized and reported by Ezema and co-workers [12] as well as by Ayuk and coworkers [13]. Although the synthesis of the type 4 derivative was described in our recent work [13], but that of the type 5 with dihalide atoms has not been reported.
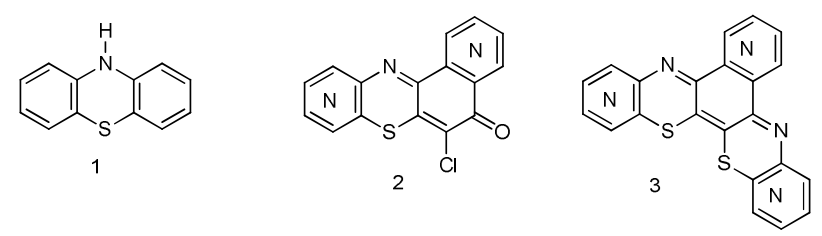

Figure 1. Structures of non-aza-linear-phenothiazine 1, the non-linear azaphenothiazine derivatives with a monohalide atom 2 and the nonlinearaza - [1, 4] benzothiazino [3, 2-c] derivative 3 .
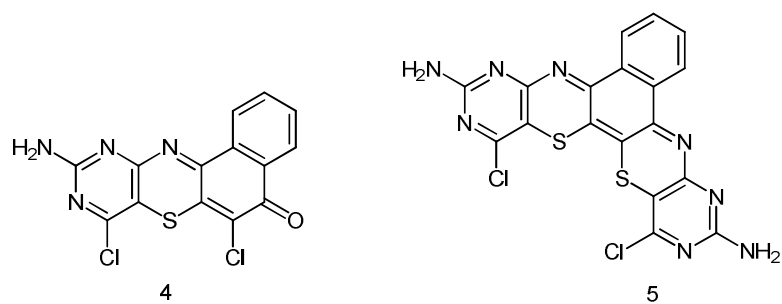

Figure 2. Structures of two dichloro derivatives of phenothiazine, 10-amino6, 8-dichloro-9, 11-diaza benzo [a] phenothiazin-5-one 4 and 7,14-diamino9-12-dichloro-6, 8, 13, 15-tetraazabenzo [a] [1, 4] benzothiazino [3, 2-c] phenothiazine 5 . 
Therefore, in furtherance of the above, we hereby report the synthesis of two dichloro derivatives of phenothiazine 10amino-6,8-dichloro-9,11-diaza benzo[a]phenothiazin-5-one 4 and 7,14-diamino-9-12-dichloro-6, 8, 13, 15-tetraazabenzo [a] $[1,4]$ benzothiazino $[3,2-c]$ phenothiazine 5 .

\section{Materials and Methods}

The reagents used were sourced locally from commercial chemical shops and were obtained in sealed containers and used without further purification. The melting points of the synthesized compounds were determined in open capillary tubes and are uncorrected. The UV-Vis spectra were recorded in DMF on a UV-2500PC series V2.30 spectrum version at NARICT, Zaria, Nigeria, using matched $1 \mathrm{~cm}$ quartz cells. Absorption maxima are given in nanometer $(\mathrm{nm})$ while the numbers in parenthesis are $\varepsilon$-values. Infrared Spectral data were obtained on FTIR-8400S (Fourier Transform Infrared Spectrophotometer), NARICT in Zaria, Nigeria using $\mathrm{KBr}$ disc and absorptions are given per centimeter $\left(\mathrm{cm}^{-1}\right)$. Nuclear magnetic resonance $\left({ }^{1} \mathrm{H}-\mathrm{NMR}\right.$ and $\left.{ }^{13} \mathrm{C}-\mathrm{NMR}\right)$ were determined using Varian mercury 200 BB spectrometer at Obafemi Awolowo University Ile-Ife, Nigeria. (Chemical Shifts are reported on $\delta$ scale relative to tetramethylsilane (TMS) as an internal standard). The analytical samples were obtained by recrystallization from acetone.

Compounds 7 and 8 were synthesized as described in the literature [14].

\subsection{0-Amino-6, 8-dichhloro-9,11-diazabenzo [a] Phenothiazin-5-one 4}

A mixture of 2, 6-diamino-4-chloropyimidin-3-thiol 8 $(4.0 \mathrm{~g}, 0.023 \mathrm{~mole})$ and anhydrous sodium carbonate $(5.0 \mathrm{~g}$, $0.050 \mathrm{~mole})$, benzene $(40 \mathrm{ml})$ mixed with DMF $(3.0 \mathrm{ml})$ were charged into a three neck reaction flask equipped with a magnetic stirring bar and a reflux condenser. The mixture was stirred while heating on a water bath at $70-75^{\circ} \mathrm{C}$ for 45minutes. 2,3-dichloro-1,4-naphthoquinone $9 \quad(4.5 \mathrm{~g}$, 0.020 mole) was added and the entire mixture was refluxed with continuous stirring for $7 \mathrm{hr}$. at temperature of $75^{\circ} \mathrm{C}$. The color of the reaction mixture changed from bright yellow to brown and then to reddish brown and finally to intense red as the reaction progressed. At the end of $7 \mathrm{hr}$, the solvent was distilled off and the slurry poured into crushed ice and stirred to dissolve the inorganic materials. It was filtered and dried to give a reddish powder which was recrystallized from acetone to give 10-amino-6, 8-dichloro-9, 11-diazabenzo [a] phenothiazine-5-one 5 as the product, melting at $180^{\circ} \mathrm{C}$, yield: $86.12 \%$. UV-Vis $\lambda \max$ (Acetone), 502nm (2.61), 280nm (1.46), 240nm (2.54). IR (KBr): $3964 \mathrm{~cm}^{-1} \mathrm{~N}-\mathrm{H}$ stretching, 2932 $\mathrm{cm}^{-1} \mathrm{C}-\mathrm{H}$ aromatic stretching, $2931 \mathrm{~cm}^{-1}$ $(\mathrm{C}=\mathrm{C}$ stretching $), 1670 \mathrm{~cm}^{-1}(\mathrm{C}=\mathrm{O}$ stretching $), 1566 \mathrm{~cm}^{-1}$, $(\mathrm{C}=\mathrm{N}), 1128 \mathrm{~cm}^{-1}$ (C-S stretching), $804 \mathrm{~cm}^{-1}$ (C-Cl bending), of the benzene ring. ${ }^{1} \mathrm{H}-\mathrm{NMR}$ (Acetone): $87.96-7.72(4 \mathrm{H}, \mathrm{m})$ corresponding to aromatics protons, $\delta 3.22-3.39(2 \mathrm{H}, \mathrm{s})$ due to the $\mathrm{NH}_{2} .{ }^{13} \mathrm{C}-\mathrm{NMR}$ (Acetone): $\delta 181.7(\mathrm{C}=\mathrm{O}), \delta$ 125.6$133.8(4 \mathrm{C}, \mathrm{m})$ of benzene, $\delta$ 29.1-29.5 (2C, d) C-Cl, $\delta 43.6$ (3C, d) C-N, $\delta 134.6(3 \mathrm{C}, \mathrm{d}) \mathrm{C}=\mathrm{N}, \delta 151.2(1 \mathrm{C}, \mathrm{d}) \mathrm{C}-$
$\mathrm{NH}_{2} . \mathrm{MS} \quad(\mathrm{m} / \mathrm{z}) \quad 347.96\left(\mathrm{M}^{+} \quad 100.0 \%\right), \quad 349.96(68.7 \%)$, 348.97(15.2\%); exact mass calculated for $\mathrm{C}_{14} \mathrm{H}_{9} \mathrm{C}_{12} \mathrm{~N}_{4} \mathrm{OS}=$ 347.96 ; Found $=349.19$.

\subsection{7, 14-Diamino-9, 12-dichloro-6, 8, 13, 15-tetraazabenzo [a] [1, 4] Benzothiazin [3, 2, c] Phenothiazine 5}

2,6-Diamino-4-chloropyimidin-3-thiol $8 \quad(2.50 \mathrm{~g}$, $0.02 \mathrm{~mole})$, anhydrous sodium carbonate $(4.00 \mathrm{~g}, 0.040 \mathrm{~mole})$ and benzene $(30.00 \mathrm{ml})$ mixed with DMF $(2.00 \mathrm{ml})$ were charged into a $250 \mathrm{ml}$ three neck round bottom flask equipped with magnetic stirring bar and a reflux condenser, thermometer. The mixture was stirred while heating on a water bath at $70-75^{\circ} \mathrm{C}$ for $45 \mathrm{~min}$. 10-amino-6, 8-dichloro-9, 11-diazabenzo [a] phenothiazine-5-one $4(4.00 \mathrm{~g}, 0.011 \mathrm{~mole})$ was added and the stirring continued while maintaining the same temperature for $9 \mathrm{hr}$.

The color of the reaction mixture changed from light red to deep red as the reaction progressed. At the end of $9 \mathrm{hr}$, the solvent was distilled off and the slurry was poured into crushed ice, stirred to dissolve inorganic matter. The solution was filtered, dried and recrystallized from acetone to give 7 , 14-diamino-9, 12-dichloro-6, 8, 13, 15-tetraazabenzo[a] [1, 4] benzothiazin-[3, 2, c] phenothiazine as the product, melting at $300^{\circ} \mathrm{C}$, yield: $89.8 \%$.

$\mathrm{UV}-\mathrm{Vis} \lambda \max$ (Acetone), 488nm ( $\varepsilon$ 2.54), 276nm (1.43), $237 \mathrm{~nm}$ ( $\varepsilon 1.23$ ), IR (KBr): $3474 \mathrm{~cm}^{-1} \mathrm{~N}-\mathrm{H}$ stretching, $2932 \mathrm{~cm}^{-}$ 1 (C-H stretching), $1588 \mathrm{~cm}^{-1} \quad\left(\mathrm{C}=\mathrm{N}\right.$ stretching), $1362 \mathrm{~cm}^{-1}$ $\left(\mathrm{C}=\mathrm{C}\right.$ stretching), $\quad 1128 \mathrm{~cm}^{-1}(\mathrm{C}-\mathrm{S} \quad$ stretching $), \quad 1005 \mathrm{~cm}^{-1}$, $805 \mathrm{~cm}^{-1}$ (C-Cl bending). ${ }^{1} \mathrm{H}-\mathrm{NMR}$ (Acetone): $\delta$ 7.96-7.72 $(4 \mathrm{H}, \mathrm{m})$ corresponding to aromatics protons, $\delta 3.40-3.22(4 \mathrm{H}$, d) assigned to $\mathrm{NH}_{2} \cdot{ }^{13} \mathrm{C}-\mathrm{NMR}$ (Acetone): $\delta$ 125.6-134.6 (4C, d) of benzene, $\delta$ 29.1-29.5 (2C, d) $\mathrm{C}-\mathrm{Cl}, \delta 43.6(4 \mathrm{C}$, multiplet), $\delta$ 131.6-134.6 (4C,) $\mathrm{C}=\mathrm{N}, \delta 205.3(2 \mathrm{C}, \mathrm{d}) \mathrm{C}-\mathrm{NH}_{2}$,

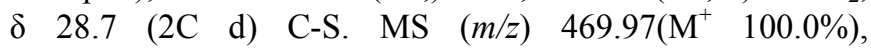
471.97(64.9\%). 470.97(24.0\%); Exact mass calculated for $\mathrm{C}_{18} \mathrm{H}_{8} \mathrm{C}_{12} \mathrm{~N}_{8} \mathrm{~S}_{2}=467.97$ : Found $=471.35$.

\section{Results and Discussions}

2,6-diamino-4-chloropyrimidine 6 was subjected to thiocyanation to give 2,6-diamino-4-chloro-3thiocyanatopyrimidine 7 which was hydrolyzed by refluxing with $20 \%$ sodium hydroxide, followed by neutralization with acetic acid to give the key intermediate 2, 6-diamino-4chloropyrimidine-3-thiol 8 in good yield as shown in figure 3 below [12], [13];

10-amino-6, 8-dichloro-9, 11-diazabenzo [a] phenothiazine5-one 4 was synthesized by the condensation reaction of the key intermediate 2, 6-diamino-4-chloropyrimidin-3-thiol 8 with 2, 3-dichloro-1, 4-naphthoquinone 9 using a mixture benzene/DMF as the reaction solvent in the presence of anhydrous sodium carbonate at $70-75^{\circ} \mathrm{C}$ for $9 \mathrm{hrs}$, while $7,14-$ diamino-9, 12-dichloro-6, 8, 13, 15-tetraazabenzo [a] [1, 4] benzothiazin - $[3,2$, c] phenothiazine 5 was prepared by reacting compound 4 with a second molecule of 2,6-diamino4-chloropyrimidin-3-thiol 8, using the same reaction conditions given above. Figure $4 \mathrm{a}$ and figure $4 \mathrm{~b}$ below shows the equation of the reaction. 
<smiles>Nc1cc(Cl)nc(N)n1</smiles>

Figure 3. Synthesis of the key intermediate, 2, 6-diamino-4-chloro-pyrimidine-3-thiol 8.<smiles>Nc1nc(N)c(S)c(Cl)n1</smiles><smiles>O=C1C(Cl)=C(Cl)C(=O)c2ccccc21</smiles>

\section{$\underset{\mathrm{DMF} / \mathrm{C}_{6} \mathrm{H}_{6} \text {, Reflux }}{\stackrel{\mathrm{Na}_{2} \mathrm{CO}_{3} \text { (anhy) }}{\longrightarrow}}$ $70^{\circ} \mathrm{C}-75^{\circ} \mathrm{C}, 7 \mathrm{hr}$.}<smiles>Nc1nc(Cl)c2sc3c(Cl)c(=O)c4ccccc4c-3nc2n1</smiles>

4

Figure 4a. The synthesis of 10-amino-6, 8-dichloro-9, 11-diazabenzo[a]phenothiazine-5-one 4.<smiles>Nc1nc(Cl)c2sc3c(Cl)c(=O)c4ccccc4c-3nc2n1</smiles>

4<smiles>Nc1nc(N)c(S)c(Cl)n1</smiles>

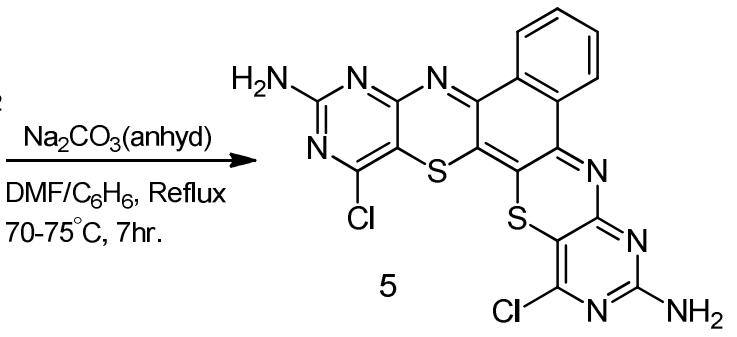

Figure 4b. The synthesis of 7,14-diamino-9, 12-dichloro-6, 8, 13, 15-tetraazabenzo [a] [1, 4] benzothiazin-[3, 2, c] phenothiazine 5 .

The IR and ${ }^{13} \mathrm{CNMR}$ spectra of compound 4 showed absorption bands at $1670 \mathrm{~cm}^{-1}$ and $\delta 181.7$, which indicate the presence the carbonyl group, but on these were not observed in the spectra of compound 5. These revelations are consistent with the assigned structures of the above compounds. The mechanism for the formation of compound 4 is described thus; the first step is the abstraction of a proton from the mercapto group of the thiol 8 by the base to form a mercapto ion 10. The mercapto ion formed, mounts a nucleophilic attack on the chlorine atom of the naphthoquinone 9 to form the sulphide 11, which cyclizes by the nucleophilic attack of the amino group of the thiol on the carbon of the carbonyl group of compound 9 followed by the loss of water to give compound of interest [12], [13] as shown in figure 5 below.

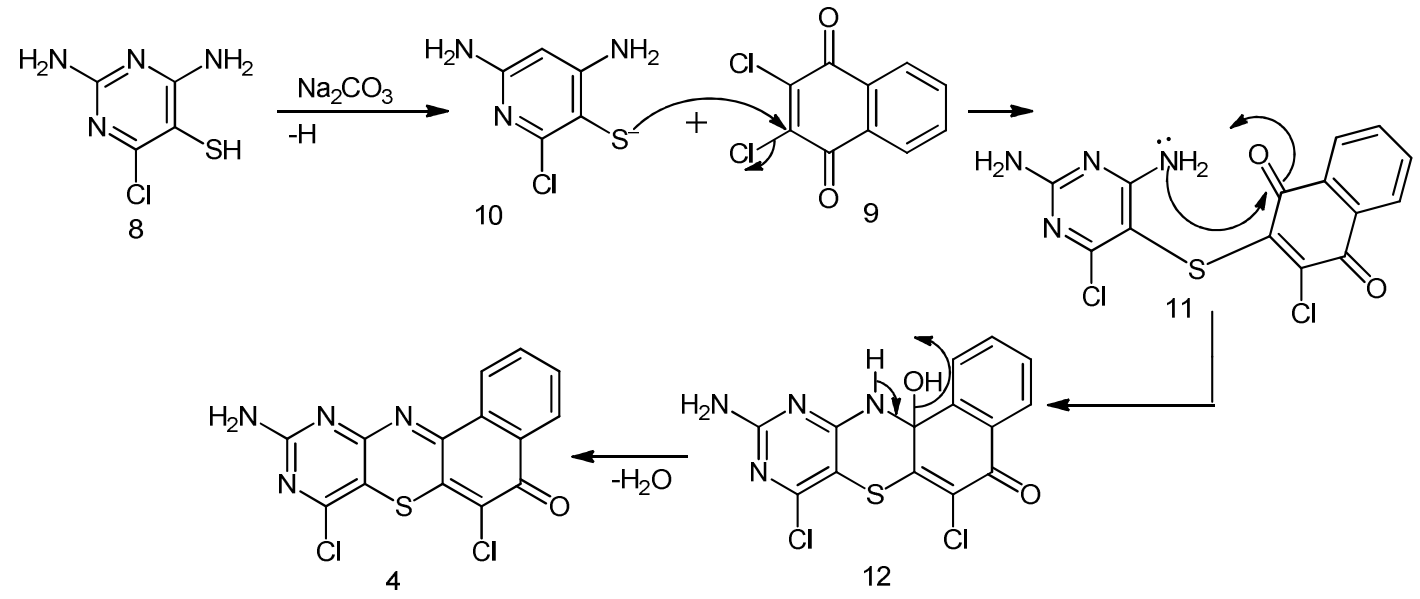

Figure 5. The reaction mechanism of 10-amino-6, 8-dichloro-9,11-diazabenzo [a] phenothiazine-5-one 4.

The infrared spectrum, of compound 4 showed a lowering of the carbonyl $[\mathrm{C}=\mathrm{O}]$ absorption from the expected $1700 \mathrm{~cm}^{-}$ ${ }^{1}$ to $1670 \mathrm{~cm}^{-1}$. This is due to the ionic resonance contribution which increases the $[\mathrm{C}=\mathrm{O}]$ bond length with its attendant decrease in the vibration frequency of absorption [12], [13], [14], as shown in figure 6 below; 


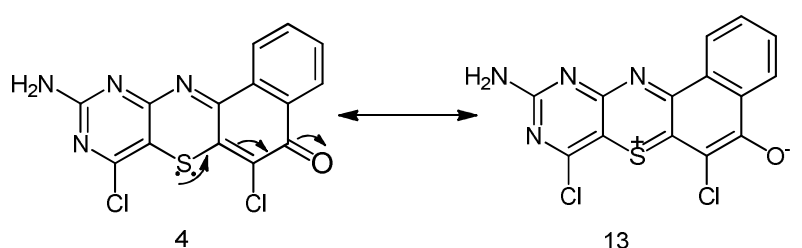

Figure 6. The mechanism showing the ionic resonance contribution which increases the $[C=O]$ bond length that results to a decrease in the vibration frequency of absorption.

In proton magnetic resonance spectrum $\delta 3.22-3.39$ is due to the amine proton $\mathrm{NH} 2$, while $\delta 7.72-7.96$ is due to $4-\mathrm{H}$ attached to benzene (C-1, C-2, C-3, C-4), these are consistent with the assigned structure. In ${ }^{13} \mathrm{C}-\mathrm{NMR}$ the peak at $\delta 181.7$ is due to the carbonyl carbon.

7, 14-Diamino-9, 12-dichloro-6, 8, 13, 15-tetraazabenzo [a] $[1,4]$ benzothiazin- $[3,2$, c]phenothiazine 5 was prepared by reacting compound 4 with a second molecule of 2,6diamino-4-chloropyrimidin-3-thiol 8 , using the same reaction conditions. This was possible because of the presence of an active chloride atom and the carbonyl functionality at the $5^{\text {th }}$ and the $6^{\text {th }}$ positions of compound 4 respectively [12], [13], [14]. The absence of signal at $\delta 181.7$ of ${ }^{13} \mathrm{C}-\mathrm{NMR}$ spectrum of compound 5 further supports the structure assigned to it.

The mechanism of this reaction is similar to that of compound 4, thus: Compound 5 is probably formed by initial nucleophilic attack by the thio-pyrimidine ion on compound 4 by displacing the reactive halogen group to form a diaryl sulphide intermediate 16 [15], [16]. Condensation of the amino and the carbonyl groups of 16 followed by the loss of a water molecule gave 7, 14-diamino-9, 12-dichloro-6, 8, 13, 15-tetraazabenzo [a] $[1,4]$ benzothiazin- $[3,2, \mathrm{c}]$ phenothiazine 5 as shown in figure 7 below.

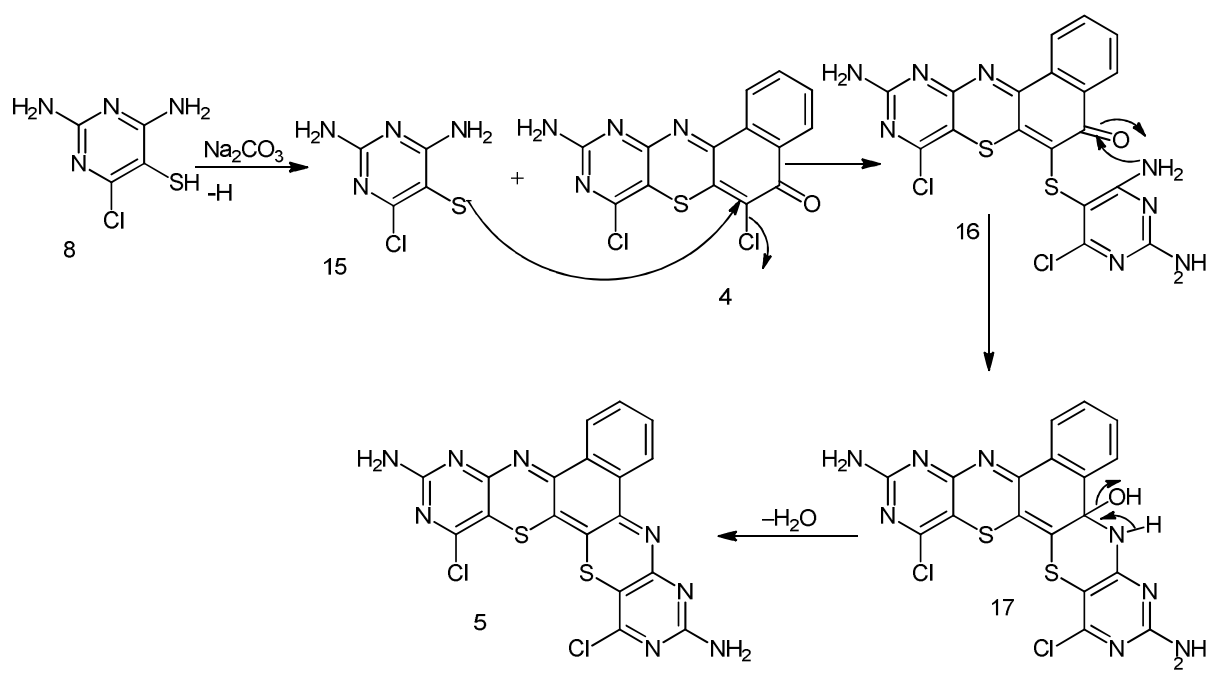

Figure 7. The reaction mechanism of 7, 14-diamino-9, 12-dichloro-6, 8, 13, 15-tetraazabenzo [a] [1, 4] benzothiazin-[3, 2, c] phenothiazine 5 .

Table 1. Spectra data of compound 4 and 5 .

\begin{tabular}{lllll}
\hline Compound & UV-Vis(EtOH) $\lambda_{\max }(\mathbf{n m})$ & $\mathbf{I R}(\mathbf{K B r}) \mathbf{v m a x}\left(\mathbf{c m}^{-1}\right)$ & ${ }^{1}$ HNMR(DMSO) $\boldsymbol{\delta}$ & ${ }^{13} \mathbf{C N M R}(\mathbf{D M S O}) \boldsymbol{\delta}$ \\
& & $3964.81 \mathrm{~cm}^{-1}(\mathrm{~N}-\mathrm{H}) ; 2932 \mathrm{~cm}^{-1}(\mathrm{C}-\mathrm{H}) ;$ & & \\
4 & $502.00(2.61) ; 280.50$ & $1670.41 \mathrm{~cm}^{-1}(\mathrm{C}=\mathrm{O}) 1566.25 \mathrm{~cm}^{-1}(\mathrm{C}=\mathrm{N}) ;$ & $7.96(\mathrm{~m}, 2 \mathrm{H}) ; 7.72(\mathrm{~m}, 2 \mathrm{H})$ & $181.7(\mathrm{C}=\mathrm{O}), 151.2(\mathrm{C}=\mathrm{N})$. \\
& $(3.1 .46) ; 240.00(2.54)$ & $1426.00 \mathrm{~cm}^{-1}(\mathrm{C}=\mathrm{C}) ; 1128.00 \mathrm{~cm}^{-1}(\mathrm{C}-\mathrm{S}) ;$ & $3.39(\mathrm{~s}, 1 \mathrm{H}) ; 3.22(\mathrm{~s}, 1 \mathrm{H})$ & $29.1(\mathrm{C}-\mathrm{C})$ \\
& & $710.79 \mathrm{~cm}^{-1}(\mathrm{C}-\mathrm{Cl})$ & & \\
& & $3474 \mathrm{~cm}^{-1}(\mathrm{~N}-\mathrm{H}) ; 2932 \mathrm{~cm}^{-1}(\mathrm{C}-\mathrm{H}) ; 1588 \mathrm{~cm}^{-1}$ & $7.96(\mathrm{~m}, 2 \mathrm{H}) ; 7.72(\mathrm{~m}, 2 \mathrm{H}) ;$ & $150.1(\mathrm{C}=\mathrm{N}) ; 134.6-131.6$ \\
5 & $488.00(2.5411) ; 276.50$ & $(\mathrm{C}=\mathrm{N}) ; 1362 \mathrm{~cm}^{-1}(\mathrm{C}=\mathrm{C}) ; 1128 \mathrm{~cm}^{-1}(\mathrm{C}-\mathrm{S}) ;$ & $3.40(\mathrm{~d}, 2 \mathrm{H}) ; 3.22(\mathrm{~d}, 2 \mathrm{H})$ & $(\mathrm{C}=\mathrm{C}) 43.6-29.1(\mathrm{C}-\mathrm{C})$ \\
\hline
\end{tabular}

Table 2. Physical and analytical data of compound 4 and 5.

\begin{tabular}{lllllll}
\hline Compound & Melting point $\left({ }^{\circ} \mathbf{C}\right)$ & Color & \% Yield & Calculated Mass(g) & Found (g) & Molecular Formula \\
\hline 4 & 180 & Reddish & 86.1 & 347.96 & 349.19 & $\mathrm{C}_{14} \mathrm{H}_{9} \mathrm{C}_{12} \mathrm{~N}_{4} \mathrm{OS}$ \\
5 & 300 & Reddish & 89.9 & 469.97 & 471.35 & $\mathrm{C}_{18} \mathrm{H}_{8} \mathrm{C}_{12} \mathrm{~N}_{8} \mathrm{~S}_{2}$ \\
\hline
\end{tabular}

\section{Conclusions}

The synthesis of the phenothiazine derivatives discussed above was carried out using simple commercially available starting materials. The methods employed are straight forward and stereo-selective products were obtained. These newly synthesized compounds will be useful in pharmaceutical, textile, petroleum, agricultural industries etc.
The high melting points exhibited by these compounds suggest that they can be used as thermal stabilizers. Also, due to their highly coloured nature, they are suitable to be used as vat dyes. However, studies in their dying and antimicrobial activity are ongoing in our laboratory.

From the spectroscopic data assigned to the structures of the above synthesized compounds, their molecular formulae are $\mathrm{C}_{14} \mathrm{H}_{9} \mathrm{Cl}_{2} \mathrm{~N}_{4} \mathrm{OS}$ and $\mathrm{C}_{18} \mathrm{H}_{8} \mathrm{Cl}_{2} \mathrm{~N}_{8} \mathrm{~S}_{2}$ respectively. 


\section{Acknowledgements}

We are very grateful to the Vice Chancellor of Godfrey Okoye University, Ugwuomu-Nike, Enugu, Nigeria, Rev. Prof. Christian Anieke, for providing a comfortable environment for academic work and research. We also thank the staff of Chemical Science Department Laboratory of the above University, for their technical assistance.

\section{References}

[1] Agata Jaszczyszyn; Kazimierz Gasiorowski; Piotr Switek; Wiesaw Malinka; Katarzyna Cieoelik-Boczula; Joanna Petrus; Bogusawa Czarnik-Matusewicz. Chemical structures of phenothiazines and their biological activity. Institute of Pharmarcology Polish Academy. 2012, 64, 16-23.

[2] Raval J; Desai KK. Synthesis and antimicrobial activity of new triazolopyridinyl Phenothiazines. ARKIVOC 2005; xiii: 21.

[3] Smith N. L; Formation and oxidation of some phenothiazine derivatives. J. Org. Chem. 1951: 16: 415-418.

[4] Massie S. P. The Chemistry of Phenothiazines, Chem. Rev $1954 ; 54 ; 797-833$.

[5] Massie S. P; Kadaba P. K; Ring Derivatives of Phenothiazines. The Synthesis of 1-substituted Phenothiazines by Thionation. J. Org. Chem. 1956: 21: 347-348.

[6] Okafor, C. O. Chemistry and applications of angular phenothiazines. Dyes and Pigments, 1986, 7 (4), 249-287.

[7] Okafor, C. O; Okerulu I. O; Okeke S. I; Vat dyes from new heterocyclic ring systems. Dyes and Pigments 1987, 8, 11-24.
[8] Gupta R. R., Kumar M; Synthesis, properties and reactions of phenothiazines in Phenothiazines and 1,4-Benzothiazines; Chemical and Biomedical Aspects, 1988, Gupta R. R. Ed, pp 1-46 Elsevier, Amsterdam.

[9] Okoro, U. C; The first analogues of dibenzotriphenodithiazine ring systems. Ind. J. Chem. 1991, 30B (118), 22-24.

[10] Odin E. M; Onoja P. K. and Saleh J. F; Synthesis, characterization and neuropharmacological activity of angular pentacyclic phenothiazine. Int. J. Phy. Sc. 2013, 8 (26), 1374-1381.

[11] Amit R. Trivedi; Arif B. Siddiqui; and Viresh H. Shah. Design, synthesis, characterization and antitubercular activity of some 2-heterocycle-substituted phenothiazines. ARKIVOC 2008 (ii) $210-217$.

[12] B. E. Ezema; C. O. Okafor; C. G. Ezema and A. E. Onoabedje. Synthesis of new diaza angular and tetraazacomplex phenothiazine rings. Chemical and Processing Engineering Research, 2012 3, 40-47.

[13] Ayuk, E. L; A. N Njokunwogbu; S. U. Ilo; G. A. Engwa; T. O. Oni; I. k. Obiudu. Synthesis of New Tetracyclic and Hexacyclic Non-Linear Phenothiazine Derivatives. Int. Journal of Scientific \& Engineering Research, 2015, 6, 1-8.

[14] Ayuk, Eugene L; Nweke, Cletus M; Agu, Ifeoma S; An Efficient Palladium Catalyzed Synthesis of Non-Linear 6, 8, Diaryl Diazaphenothiazinone Derivatives. Int.Journal of Advanced Research in Chemical Science, 2015, 2, 64-71.

[15] Okoro, U. C. and Ofoefule, A. U.; Synthesis of aza angular Phenothiazines (2008), Ind. Journal Chem. 18(13) 109-115.

[16] Okoro U. C and Ezema B. E. Synthesis of 1, 11-diaza-5Hbenzo [a] phenothiazine-5-one. (2006), IJC 16(2), 115-120. 